\title{
The Effect of Service Quality on Customer Satisfaction in Selected Private Banks (In Case of Wolaita Sodo Town)
}

\author{
Wondmagegn Urgessa Urissa \\ College of Business and Economics, Department of Management, Wolaita Sodo University, Ethiopia
}

\begin{abstract}
In the competitive market, banks in both public and private sectors apply different strategies to improve the quality of their services provided. However, there is a lack of recent evidence to show how the quality of these services affects customer satisfaction, leaving a significant fleabag in Ethiopian literature. Therefore, this study attempted to explore the effect of service quality of private banks on customer satisfaction. Data were collected through questionnaire from a sample of 360 bank customer. The respondents were selected using simple random sampling method. The data collected from the questionnaire were analyzed using Statistical tools such as mean, standard deviation, correlation, and multiple regression analysis. The finding of this study also indicates that customers were most satisfied with the assurance dimensions of service quality. On the contrary, customers were less satisfied with reliability and empathy dimensions of service quality. The results also indicate that unlike responsiveness the four service quality dimensions (tangibility, empathy, assurance and reliability) have positive and significant effect on customer satisfaction.
\end{abstract}

Keywords: Customer Satisfaction, Service Quality,

DOI: $10.7176 / \mathrm{EJBM} / 11-19-03$

Publication date:July $31^{\text {st }} 2019$

\subsection{INTRODUCTION}

The banking sector, as the main aspect of the financial sector, provides very important and productive strategy to manipulate stable of that sector achieving financial inclusion, maintaining favorable asset and balancing capital and liquidity level of the economy (Silva, 2009). Bank is a customer oriented services industry. A bank depends upon the customers for their survival in the market. The customer is the focus and customer service is the differentiating factors (Guo et al., 2008).

Service quality is defined as customer's overall conception of the relative inferiority or greatness of the organization and its service (Bitner \&Hubbert, 1994; Keiningham et al., 1995).

According to Service Quality Theory introduced by Oliver (1980), if performance of the service firm does not meet customer's expectation, customers will judge that firm has 'low quality' and also, if performance of that service firm exceeds the expectation of the customers, customers will judge firm has 'high quality'

Customer satisfaction is crucial in the banking sector because of the special nature of the financial services which are characterized by intensive contacts with customers who have different needs and require customized solutions" (Molina et al., 2007). "Customer satisfaction is known to be one of the most important and serious issues towards success in today's competitive business environment, as it affects company market shares and customer retention" (Ooi,et al., 2011).

The term satisfaction is a feeling (Kotler,2009) that extending across the entire consumption horizon (Oliver, 1980). In a simply, satisfaction determined by comparing costs which customers give up to get a service and reward which customers receive as response (Tam, 2004). Therefore, customer satisfaction is defined as an outcome of purchase and use came as a result of buyers' comparison of the reward and costs of purchase (Churchill \& Surprenant,1982).

Many empirical and conceptual studies have been done on customer service quality and customer satisfaction.

The finding of Mohammad and Alhamadani (2011) indicated that service quality is an important antecedent of customer satisfaction.

Parasuraman et al., (1985) "found that service quality is significant predictor of customer satisfaction by using SERVQUAL instrument." Service quality and customer satisfaction "have been identified as key elements of the servic e-profit chain" (Heskett et al., 1997).

The successfulness of organization is, therefore, determined partly by the customer satisfaction.

Accordingly, Newman and Cowling (1996) "believes that excellent service quality is vital to business profitability and survival." Thus, from the finding of Newman and Cowling, the researcher understands that if service quality is going down in the organization, it will have negative effects on the organization's profitability. This study, therefore, investigated the effect of service quality on customer satisfaction in selected private banks in Wolaita sodo town.

\subsection{General Objectives}

The main objective of this study was to examine the effect of service quality on customer satisfaction in selected 
private banks in Wolaita sodo town.

\subsection{Hypothesis of the study}

To meet the objectives the following hypotheses were investigated:

\section{Hypothesis 1}

Ho1: Tangible will not have a positive and significant effect on customer satisfaction.

Hypothesis 2

Ho2: Reliability will not have a positive and significant effect on customer satisfaction.

Hypothesis 3

Ho3: Responsiveness will not have a positive and significant effect on customer satisfaction.

Hypothesis 4

Ho4: Assurance will not have a positive and significant effect on customer satisfaction.

\section{Hypothesis 5}

Ho5: Empathy will not have a positive and significant effect on customer satisfaction

\section{LITERATURE REVIEW}

\section{Service quality}

Service quality is considered an important tool for a firm's struggle to differentiate itself from its competitors (Ladhari, 2008). Service quality has received a great deal of attention from both academicians and practitioners (Negi,2009) and service marketing literature defined service quality as the overall assessment of a service by the customer (Eshghi et al., 2007). Bitner and Hubbert (1994) "define service quality as the customers' overall impression of the relative inferiority or superiority of the organization and its services." Gronroos (1984) "identified service quality as the evaluation $\mathrm{n}$ process outcome, in which customers are involved and where a certain experience is always compared to the perceived service received." "Service quality is not objectively measured according to some technical standards but is subjectively felt by customers and measured relative to customer-determined standards" (Kwortnik, 2005). Berry et al ., (1990) also "defined service quality as the discrepancy between customers' expectations or desire and their perceptions." "The previous literature suggests that the evaluati on of quality in services is more difficult than goods (Parasuraman et al., 1985) and that delivering quality services is increasingly recognized as the key to success for service providers" (Cronin and Taylor, 1992 as cited in Wei 2010). But, "perceived service quality has confirmed to be a complex concept to understand" (Brady and Cronin, 2 001, pp.34). Therefore, Rust and Oliver (1994) propose that it is essential for companies to develop the awareness of customers' perceptions of service quality.

\section{Customer Satisfaction}

According to, Magesh (2010), satisfaction means a feeling of pleasure because one has something or has achieved something. It is an action of fulfilling a need, desire, demand or expectation. Customers compare their expectations about a specific product or services and its actual benefits. According to Robert W.L. (2005) "customer service $\mathrm{i}$ $\mathrm{s}$ defined as the ability of knowledgeable, capable and enthusiastic employees to deliver products and services to their internal and external customers in a manner that satisfies identified and unidentified needs and ultimately result in positive word-of-mouth publicity and return business."

Customer satisfaction has become important due to increased competition as it is considered very important factor in the determination of bank's competitiveness (Berry et al., 2002). Continuous measurement of satisfaction level is necessary in a systematic manner (Chakravarty et al., 1996). Because satisfied customer is the real asset for an organization that ensures long-term profitability even in the era of great competition.

\section{Characteristics of Services}

According to Bitner et al., (1993) service has four characteristics: intangibility, inseparability, heterogeneity and pershability.

\section{Intangibility of Services}

Regan (1963) "introduced the idea of services being activities, benefits or satisfactions which are offered for sale, or are provided in connection with the sale of goods". The degree of intangibility has been suggested as a means of differentiating tangible products with services (Levitt, 1981).

\section{Inseparability of Services}

Inseparability is taken to reflect the simultaneous delivery and consumption of services (Regan 1963; Wyckham et al 1975; Donnelly 1976; Grönroos 1978; Zeithaml 1981; Carman and Langeard 1980; Zeithaml et al., 1985; Bowen 1990 and Onkvisit and Shaw 1991) and it is believed to enable consumers to affect or shape the performance and quality of the service (Grönroos, 1978; Zeithaml, 1981 as citied in Wolak et al., 1998).

\section{Heterogeneity of Services}

Heterogeneity "reflects the potential for high vari ability in service delivery" (Zeithaml et al., 1985). This is a particular problem for services with high labor content, as the service performance is delivered by different people and the performance of people can vary from day to day (Rathmell, 1966; Carman and Langeard, 1980; Zeithaml, 1985; Onkvisit and Shaw, 1991 as citied in Wolak et al., 1998). 


\section{Perishability of Services}

In general, services cannot be stored and carried forward to a future time period (Rathmell, 1966; Donnelly, 1976; and Zeithaml et al., 1985 as citied in Wolak et al., 1998).

\section{Relationship between Service Quality and Customer Satisfaction:}

Concerning the relationship between customer satisfaction and service quality, Oliver (1993) first suggested that service quality would be antecedent to customer satisfaction regardless of whether these constructs were cumulative or transaction-specific. In relating customer satisfaction and service quality, researchers have been more precise about the meaning and measurements of satisfaction and service quality. Satisfaction and service quality have certain things in common, but satisfaction generally is a broader concept, whereas service quality focuses specifically on dimensions of service (Wilson et al., 2008). Although it is stated that other factors such as price and product quality can affect customer satisfaction, perceived service quality is a component of customer satisfaction (Zeithaml \& Bitner, 2003). As said by Wilson et al. (2008), service quality is a focused evaluation that reflects the customer's perception of reliability, assurance, responsiveness, empathy and tangibility while satisfaction is more inclusive and it is influenced by perceptions of service quality, product price and quality, also situational factors and personal factors. The relationship between service quality and customer satisfaction is becoming crucial with the increased level of awareness among bank customers Demographic characteristics should be considered by the bank managers to understand their customers (Sureshchander et al. 2002)

\subsection{Conceptual Framework}

In this conceptual model the five Service quality dimensions have been selected form the study conducted by Parasuraman et al., (1988).

Parasuraman et al., (1985) conducted research on different service organization (Bank, Hotel, Electrical Corporation, Hospital, Transportation) by using ten service quality dimensions (tangibility, reliability, responsiveness, communication, access, competence, courtesy, credibility, security, and knowledge). Later Parasuraman et al., (1985) conducted research and then the ten dimensions were further purified and developed into five dimensions (tangibility, reliability, responsiveness, assurance and empathy). The reason behind purified the ten dimensions into five dimensions was the appropriateness of each service quality dimensions to different service organizations for example security dimension is appropriate for transportation, credibility dimension is appropriate for hotel. Therefore, this convinced me to use Parasuraman et al., (1988)'s model.

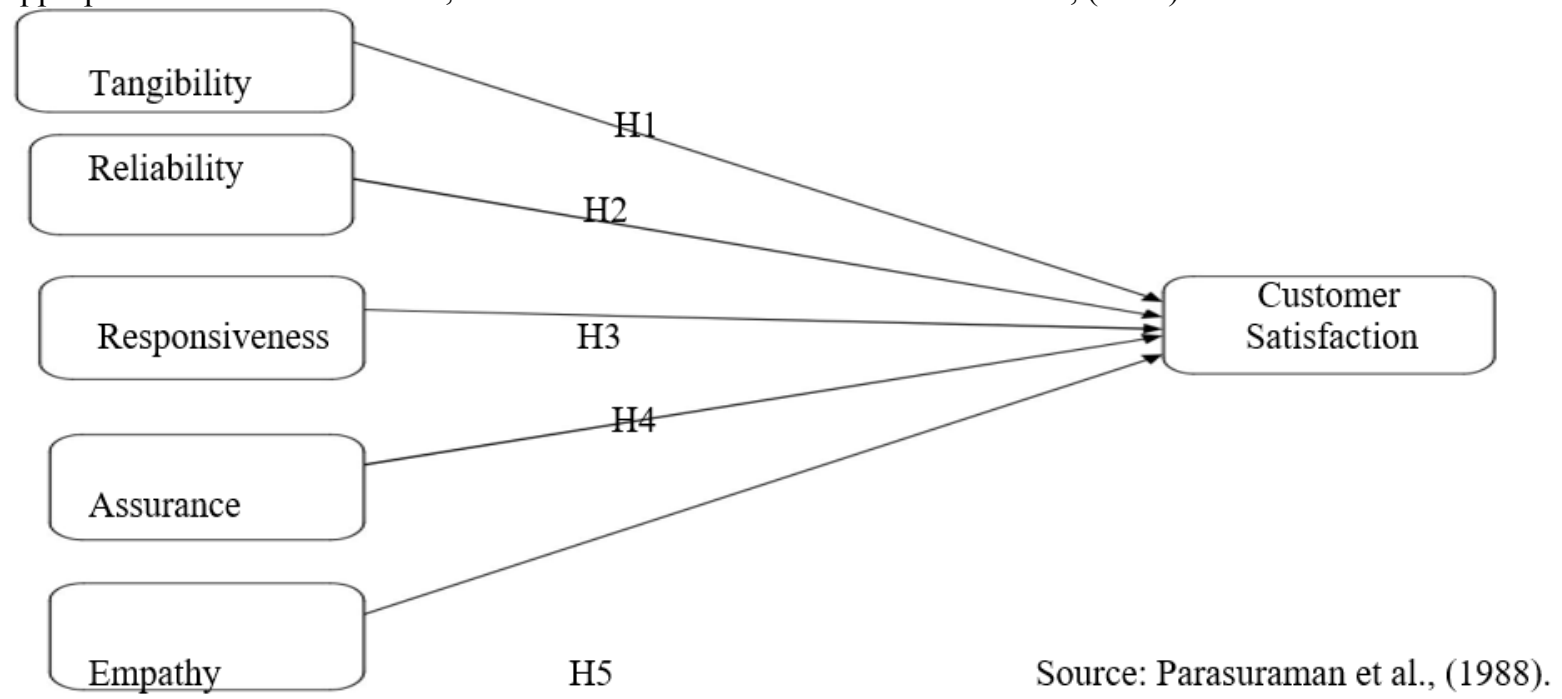

Figure 2.1. Framework of the effect of customer service quality on customer satisfaction

\section{METHODOLOGY}

\subsection{Research Design}

The research design adopted for study is both descriptive and explanatory study design using quantitative method was used to analyze for data collected from customers. The reason behind using descriptive study design is because the researcher is interested in describing the existing situation under study. This study used descriptive analysis that describes the service quality dimensions that lead to customer satisfaction. This study also used explanatory study design, to explaining, understanding, predicting and controlling the relationship between variables. The study is cross-sectional. According to Fraenkel\&Wallen, (2006), a cross-sectional survey collects information from a sample that has been drawn from a predetermined population and information is collected at just one point in time. 


\subsection{Sample size and Sampling technique}

The sample size of banks has been determined by using simple random sampling method. Out of 14 private banks, 29 percent (4 banks) were selected as a sample. The four banks were selected on the assumption that they could represent the 14 private banks. After the samples of banks have been determined, the researcher used the following sample size determination formula to determine the sample size of the population in four banks. The formula was developed by Taro Yamane (1967). It is calculated as follows

$\frac{\mathrm{N}}{\mathrm{n}=1+\mathrm{N}\left(\mathrm{e}^{-}\right)^{2}}$

$$
\text { Where } \begin{aligned}
& \mathrm{n}=\text { sample size } \\
& \mathrm{N}=\text { total population } \\
& \mathbf{e}=\text { is the level of precision or sampling error }=(0.05)
\end{aligned}
$$

Hence, the total sample size is 365 . Since the number of people in each bank is not the same, the number of samples for each bank was calculated by the following formula:

$$
\mathrm{n} 1=\frac{\mathrm{nN} 1}{\mathrm{~N}}
$$

Where $\mathrm{n}=$ total number of samples

$\mathrm{N}=$ total number of population

$\mathrm{N} 1=$ total number of population in each bank

$\mathrm{n} 1=$ number of samples in each bank

The study was conducted on 4 private bank's head offices (Berhan International bank, Abyssinia, Nib international and Awash International Bank and the total population of the study was 4178 .

Table 3.1: Number of customers and proportion of samples taken from each bank

\begin{tabular}{|l|l|l|}
\hline Banks & Number of population & Total number of sample) \\
\hline Berhan international bank & 1248 & 109 \\
\hline Abyssinia Bank & 1066 & 93 \\
\hline Nib International Bank & 982 & 86 \\
\hline Awash International Bank & 879 & 77 \\
\hline \multicolumn{1}{|c|}{ Total } & $\mathbf{4 1 7 8}$ & $\mathbf{3 6 5}$ \\
\hline
\end{tabular}

Source: Developed by researcher, 2018

After each bank sample size was determined, the researcher used simple random sampling method to select the target customers. The rationale behind using simple random sampling technique is because each member of the population will have equal chance of being selected. For primary data collection, from the total number of population (4178) the number of samples taken was 365

\section{RESULT AND DESICCATION}

Descriptive Statistics Analysis

Table 4.1 Mean and standard deviation for Abyssinia bank's Service quality dimension and Customer Satisfaction

\begin{tabular}{|l|c|c|c|}
\hline & $\mathrm{N}$ & Mean & Std. Deviation \\
\hline Tangibility & 102 & 2.8251 & .54851 \\
\hline Reliability & 102 & 2.2147 & .58742 \\
\hline Responsiveness & 102 & 3.7675 & .45865 \\
\hline Assurance & 102 & 3.9371 & .42430 \\
\hline Empathy & 102 & 2.1286 & .59789 \\
\hline $\begin{array}{l}\text { Customer } \\
\text { Satisfaction }\end{array}$ & 102 & 3.1582 & .53938 \\
\hline Valid N & 102 & & \\
\hline
\end{tabular}

Source: own survey, 2018 
Table 4.2 Mean and standard deviation for Berhan international bank's Service quality dimension and Customer Satisfaction

\begin{tabular}{|l|c|c|c|}
\hline & $\mathrm{N}$ & Mean & Std. Deviation \\
\hline Tangibility & 87 & 3.4140 & .51836 \\
\hline Reliability & 87 & 3.2430 & .58872 \\
\hline Responsiveness & 87 & 3.8568 & .46328 \\
\hline Assurance & 87 & 3.9324 & .45456 \\
\hline Empathy & 87 & 3.2564 & .58975 \\
\hline $\begin{array}{l}\text { Customer } \\
\text { Satisfaction }\end{array}$ & 87 & 3.7487 & .47574 \\
\hline Valid N & 87 & & \\
\hline
\end{tabular}

Source: own survey, 2018

Table 4.3 Mean and standard deviation for Nib international bank's Service quality dimension and Customer Satisfaction

\begin{tabular}{|l|c|l|l|}
\hline & $\mathrm{N}$ & Mean & Std. Deviation \\
\hline Tangibility & 81 & 3.6586 & .47958 \\
\hline Reliability & 81 & 2.9862 & .58647 \\
\hline Responsiveness & 81 & 3.4943 & .49694 \\
\hline Assurance & 81 & 3.8435 & .45764 \\
\hline Empathy & 81 & 3.1324 & .52546 \\
\hline $\begin{array}{l}\text { Customer } \\
\text { Satisfaction }\end{array}$ & 81 & 3.4546 & .51325 \\
\hline \begin{tabular}{l} 
Valid \\
\hline
\end{tabular} & 81 & & \\
\hline
\end{tabular}

Source: own survey, 2018

Table 4.4 Mean and standard deviation for Awash International bank's Service quality dimension and Customer Satisfaction

\begin{tabular}{|l|c|l|l|}
\hline & $\mathrm{N}$ & Mean & Std. Deviation \\
\hline Tangibility & 72 & 3.1425 & .56842 \\
\hline Reliability & 72 & 2.3423 & .53974 \\
\hline Responsiveness & 72 & 3.2549 & .54791 \\
\hline Assurance & 72 & 3.4132 & .51435 \\
\hline Empathy & 72 & 2.1324 & .58641 \\
\hline $\begin{array}{l}\text { Customer } \\
\text { Satisfaction }\end{array}$ & 72 & 3.5246 & .49826 \\
\hline \begin{tabular}{l} 
Valid N \\
\hline
\end{tabular} & 72 & & \\
\hline
\end{tabular}

Source: own survey, 2018 
As indicated in Table 4.2 customers of Berhan international bank were satisfied by the five service quality dimensions with a mean and standard deviation (tangibility 3.4140 and .51836 , reliability 3.2430 and .58872 , responsiveness 3.8568 and .46328 , assurance 3.9324 and .45456 , empathy 3.2564 and .58975 ) respectively. The highest number of mean indicated that the customers are more satisfied by service quality dimensions and the highest number of standard deviation indicated that the customers are less satisfied by service quality dimensions of the banks. However, table 4.2, 4.4 and 4.5 indicated that customers of Abyssinia, Nib international bank and Awash international bank were satisfied by only three service quality dimensions (tangibility, responsiveness and Assurance). Therefore Abyssinia, Nib international bank and Awash international banks must adopt the service quality strategies of Awash international bank.

Table4.5 Mean and standard deviation or the four bank's Service quality dimensions and Customer Satisfaction

\begin{tabular}{|l|c|c|c|}
\hline & $\mathrm{N}$ & Mean & Std. Deviation \\
\hline Tangibility & 342 & 3.7696 & .53951 \\
\hline Reliability & 342 & 2.9364 & .58520 \\
\hline Responsiveness & 342 & 3.7146 & .56009 \\
\hline Assurance & 342 & 3.8492 & .55097 \\
\hline Empathy & 342 & 2.8242 & .51837 \\
\hline $\begin{array}{l}\text { Customer } \\
\text { Satisfaction }\end{array}$ & 342 & 3.6143 & .62141 \\
\hline Valid N & 342 & & \\
\hline
\end{tabular}

Source: own survey, 2018

Table 4.5 indicates that assurance has the highest mean value and reliability and empathy have least mean value. Therefore, it may be concluded from table 4.5 that respondents are most satisfied with assurance dimensions with a mean and standard deviation of 3.8492 and 0.55097 respectively. This is followed by tangibility and responsiveness. However, customers are less satisfied with reliability and empathy at a mean of 2.9364, 2.8242 respectively. The satisfaction has a mean score 3.6143 which indicates that overall customers are slightly satisfied with the service quality of banks.

\section{$>$ Pearson Correlation analysis}

Below presents the results of Pearson correlation on the relationship between service quality dimension and customer satisfaction. 
Table 4.6.The relationship between service quality dimensions and customer satisfaction

\begin{tabular}{|l|l|c|}
\hline & & Customer Satisfaction \\
\hline Tangibility & Pearson correlation & \\
& Sig.(2-tailed) & $.832^{* *}$ \\
& $\mathrm{~N}$ & .000 \\
& 342 \\
\hline Reliability & Pearson correlation & $.756^{* *}$ \\
& Sig.(2-tailed) & .000 \\
$\mathrm{~N}$ & 342 \\
\hline Responsiveness & Pearson correlation & -.596 \\
& Sig.(2-tailed) & .080 \\
$\mathrm{~N}$ & 342 \\
\hline Assurance & Pearson correlation & $.669^{* *}$ \\
& Sig.(2-tailed) & .000 \\
& $\mathrm{~N}$ & 342 \\
\hline Empathy & Pearson correlation & $.786^{* *}$ \\
& $\mathrm{~N}$ & .000 \\
& & 342 \\
\hline
\end{tabular}

Source, Own survey, 2018

** Correlation is significant at the 0.01 level (2-tailed).

The results in table 4.6 indicate that, there is positive and significant relationship between tangibility and customer satisfaction $(\mathrm{r}=0.832, \mathrm{p}<0.01)$, reliability and customer satisfaction $(\mathrm{r}=0.756, \mathrm{P}<0.01)$, assurance and customer satisfaction $(\mathrm{r}=0.669, \mathrm{P}<0.01)$, empathy and customer satisfaction $(\mathrm{r}=0.786,<0.01)$. However, the results also indicate that, there is a negative and insignificant relationship between responsiveness and customer satisfaction $(\mathrm{r}=-0.596, \mathrm{p}>0.01)$. The finding on table 4.7 above further indicates that the highest relationship is found between tangibility and customer satisfaction $(r=0.832, p<0.01)$. Unlike responsiveness four service quality dimensions (tangibility, reliability, assurance and empathy) has a positive relationship with customer satisfaction.

\section{$>$ Multiple Regression Analysis}

The following sections present the results of multiple regression analysis.

Table 4.7 Regress Customer satisfaction on service quality dimensions

\begin{tabular}{|c|c|c|c|c|c|}
\hline \multirow{2}{*}{ Variable } & \multicolumn{2}{|c|}{$\begin{array}{l}\text { Unstandardized } \\
\text { Coefficients }\end{array}$} & \multicolumn{2}{|l|}{$\begin{array}{l}\text { Standardized } \\
\text { Coefficients }\end{array}$} & \multirow[b]{2}{*}{ Sig. } \\
\hline & B & $\begin{array}{l}\text { Std. } \\
\text { error }\end{array}$ & Beta & $\mathrm{t}$ & \\
\hline (Constant) & -.713 & .236 & & -3.002 & .003 \\
\hline Tangibility & .347 & .082 & .379 & 5.375 & $.000 * *$ \\
\hline Reliability & .315 & .098 & .312 & 4.352 & $.000 * *$ \\
\hline Responsiveness & -.096 & .113 & -.078 & -.851 & .376 \\
\hline Assurance & .362 & .074 & .287 & 4.262 & $000 * *$ \\
\hline Empathy & .416 & .103 & .326 & 3.908 & $000 * *$ \\
\hline
\end{tabular}

Source, own survey, 2018

Hypothesis testing is based on standardized coefficients beta and P-value to test whether thehypotheses are rejected or not.

Hypothesis 1

Hol: Tangibility will not have a positive and significant effect on customer satisfaction. 
Ha1: Tangibility will have a positive and significant effect on customer satisfaction.

The results of multiple regressions, as presented in table 4.7 above, revealed that tangibility has a positive and significant effect on customer satisfaction with a beta value (beta $=0.379)$, at $99 \%$ confidence level $(p<0.01)$. Therefore, the researcher may reject the null hypothesis and it is accepted that, tangibility has a positive and significant effect on customer satisfaction.

\section{Hypothesis 2}

Ho2: Reliability will not have a positive and significant effect on customer satisfaction.

Ha2: Reliability will have a positive and significant effect on customer satisfaction.

The results of table 4.7 showed that the standardized coefficient beta and $p$ value of reliability were positive and significant (beta $=0.312, \mathrm{p}<0.01$ ). Thus, the researcher may reject the null hypothesis and it is accepted that, reliability has a positive and significant effect on customer satisfaction.

\section{Hypothesis 3}

Ho3: Responsiveness will not have a positive and significant effect on customer satisfaction.

Ha3: Responsiveness will have a positive and significant effect on customer satisfaction.

As shown in table 4.8, $\mathrm{p}$-value is not significant ( $\mathrm{p}>0.01)$, and the beta value of responsiveness was negative (bata $=-0.078$ ). Therefore, the researcher fails to reject the null hypothesis and responsiveness has a negative and insignificant effect on customer satisfaction.

\section{Hypothesis 4}

Ho4: Assurance will not have a positive and significant effect on customer satisfaction.

Ha4: Assurance will have a positive and significant effect on customer satisfaction.

Table 4.7 further shows that, assurance has a positive and significant effect on customer satisfaction with a beta value (beta $=0.287)$, at $99 \%$ confidence level $(\mathrm{p}<0.01)$. Therefore, the researcher may reject the null hypothesis and assurance has a positive and significant effect on customer satisfaction.

\section{Hypothesis 5}

Ho5: Empathy will not have a positive and significant effect on customer satisfaction.

Furthermore, table 4.7 also indicates that, the standardized beta and p - value of empathy were positive (beta $=$ $0.326)$, and significant at $99 \%$ confidence level $(\mathrm{P}<0.01)$. As a result, the researcher may reject the null hypothesis. So empathy has a positive and significant effect on customer satisfaction.

In overall, the results revealed that all independent variables accounted for $80 \%$ of the variance in customer satisfaction $(\mathrm{R} 2=0.804)$. Thus, $80 \%$ of the variation in customer satisfaction can be explained by the five service quality dimensions and other unexplored variables may explain the variation in customer satisfaction which accounts for about $20 \%$, shown in table 4.7 .

Moreover, from the findings of this study, researcher found out that not all of the service quality dimensions have positive effects on customer satisfaction. Out of the five service quality dimensions four dimensions (tangibility, reliability, assurance, and empathy) have positive and significant effects on customer satisfaction. On the other hand, responsiveness has a negative and insignificant influence on customer satisfaction.

The findings of this study also indicated that tangibility is the most important factor to have positive and significant effect on customer satisfaction, followed by empathy, assurance and reliability.

\section{RESULT DISCUSSION}

Descriptive statistics (mean, and standard deviation) and correlation analysis

The finding of this study indicates that customers were most satisfied with the assurance dimensions of service quality. However, customers were less satisfied with reliability and empathy dimensions of service quality. The correlation result show that there is positive and significant relationship between tangibility and customer satisfaction, reliability and customer satisfaction, assurance and customer satisfaction, empathy and customer satisfaction. However, the results indicate that, responsiveness has a negative and insignificant relationship with customer satisfaction. The finding further indicates that the highest relationship is found between tangibility and customer satisfaction.

\section{Regressing customer satisfaction on the service quality dimensions}

The result of this study indicates that tangibility has a positive and significant effect on customer satisfaction. The finding of this study also indicates that reliability has a positive and significant effect on customer satisfaction. This finding is supported by Al-Hawary et al., (2011) reported that reliability has a positive and significant effect on customer satisfaction. However, the finding of this study indicates that responsiveness has a negative and insignificant effect on customer satisfaction.

In overall, the results revealed that all independent variables accounted for $80 \%$ of the variance in customer satisfaction $(\mathrm{R} 2=0.804)$. Thus, $80 \%$ of the variation in customer satisfaction can be explained by the five service quality dimensions and other unexplored variables may explain the variation in customer satisfaction which accounts for about $20 \%$.

Moreover, from the findings of this study, researcher found out that not all of the service quality dimensions 
have positive effects on customer satisfaction. Out of the five service quality dimensions four dimensions (tangibility, reliability, assurance, and empathy) have positive and significant effects on customer satisfaction. On the other hand, responsiveness has a negative and insignificant effect on customer satisfaction. The results of this study further indicate that tangibility is the most important factor to have a positive and significant effect on customer satisfaction.

\subsection{CONCLUSIONS}

$>$ The finding of the study also indicates that, customers were most satisfied with the assurance dimensions of service quality.

$>$ However, customers were less satisfied with reliability and empathy dimensions of service quality.

$>$ The correlation result shows that, unlike responsiveness the four service quality dimensions (tangibility, assurance, empathy and reliability) are positively and significantly related with customer satisfaction.

$>$ In terms of the stated research hypotheses the following specific empirical findings emerged from the investigation: The four service quality dimensions including tangibility, reliability, assurance and empathy have positive and significant effect on customer satisfaction.

$>$ The findings of this study also indicated that tangibility is the most important factor to have a positive and significant effect on customer satisfaction.

$>$ In addition to this, except responsiveness the four service quality dimensions significantly explain the variations in customer satisfaction.

\subsection{RECOMMENDATIONS}

- Empathy dimension was considered as one of the most important factors influencing customer satisfaction. However, the customers of private banks in Wolaita sodo town were found less satisfied in terms of the empathy dimensions.

- One way of addressing this could be by treating customer with great respect, giving individual attention to customers, serving customers based on their specific needs and treating customers in a friendly manner. This is to say, the bank management should focus on this factor to maximize customer satisfaction.

- Furthermore, reliability dimension was considered as one of the most important factors influencing customer satisfaction. However, the customers of private banks in Wolaita sodo town were found less satisfied in this regard.

- One way of handling this problem is by delivering its services at promised times, and handling customer's complaints effectively.

- The finding of the study also indicates that customers of Berhan international bank were satisfied by the five service quality dimensions (tangibility, reliability, responsiveness, assurance and empathy).

- However, customers of Abyssinia, Nib international bank and Awash international bank were satisfied by only three service quality dimensions (tangibility, responsiveness and Assurance). Therefore, Abyssinia bank, Nib international bank and Awash international banks must adopt the service quality strategies of Awash international bank.

\section{Reference}

Johnston, R. (1995). The determinants of service quality: satisfiers and dissatisfiers. International Journal of Service Industry Management, 6(5), 53-71.

Kline, R. (1998). Principles and practice of structural equation modeling. Guilford Press, NY.

Kotler, P.(2000), Marketing Management. 10th ed., New Jersey, Prentice-Hall.

Krueger, R.A. (1994). Focus groups: A practical guide for applied research. Thousand Oaks, CA: Sage Publications, Inc.

Kwortnik, R.J. (2005): 'Preparing for Disaster: Recommendations Based on the Blackout of 2003', Cornell Hotel and Restaurant Administration Quarterly, 46 (1), 47-51.

Levesque T, McDougall GHG. (1996), "Determinants of customer satisfaction in banking." International Journal of Bank Marketing; Vol. 14(7), Pp. 12-20.

Levitt T. (1981). "Marketing Intangible Products an d Product Intangibles", Harvard Business Review, 81, 94 102.

Lin, Chia Chi, (2003), "A critical appraisal of cus tomer satisfaction and ecommerce", Managerial Auditing Journal, Vol. 18 No. 3, pp. 202-212.

Lovelock, C and Wright, L. (1999), Principles of service marketing and management, Prentice-Hall: New Jersey.

Malik, E. M, Naeem B. and Arif, Z. (2011), How do service quality perceptions contribute in satisfying banking customers?, Interdisciplinary Journal of contemporary Research in Business, Vol. 3(8): 646- 653.

Mittal, V. and M. Tsiros. (1999). Attribute-level performance satisfaction, and behavioral intentions over time: A consumption- system approach. Journal of Marketing 63:88-101. 
Mohammad, S.A.A. and Alhamadani, M.Y.S. (2011), Service quality perspectives and customer satisfaction in commercial banks working in Jordan, 14 (2011): 61- 72.

Molina, A, Martín-Consuegra, D and Esteban, A. (2007), 'Relational benefits and customer satisfaction in retail banking', International Journal of Bank Marketing, Vol. 25: 4, pp 253: 271.

Munusamy, J., Chelliah, S. and Mun, W. H. (2010), Service quality delivery and its impact on customer satisfaction in the banking sector in Malaysia, International Journal of Innovation, Management and Technology, Vol. 1(4): $398-404$.

Nelson NO, Chan KW (2005). Factorial and discriminant analysis of the underpinnings of relationship marketing and customer satisfaction. Inter. J. Bank Mark, 23(7): 542-557.

Newman, K. and Cowling, A. (1996), "Service Quality in Retail Banking: The experience of Two British Clearing Banks," International Journal Of Bank Marketing, 49, 41-50.

Oliver, R.L. (1980). A cognitive model of the antecedents and consequences of satisfaction decisions. Journal of Marketing Research 17:460-469.

Oliver, R. L. (1981). Measurement and Evaluation of Satisfaction Process in Retail Setting. Journal of Retailing, $57(3), 18-48$.

Oliver, R. L. (1993). Cognitive, Affective, and Attribute Bases of the Satisfaction Response. Journal of Consumer Research, 20 (December), pp. 418-430.

Oliver, R.L. (1997). Satisfaction: A behavioral perspective on the consumer. New York, NY: Irwin McGraw-Hill.

Oliver, R. L. and Desarbo, W. S. (1988). Respones Determinants in Satisfaction Judgment. Journal of Consumer Research, Vol.14, PP.495-507.

Onkvisit S. and Shaw J.J. (1991). "Is Services Mark eting "Really” Different?", Journal of Professional Services Marketing, 7, 2, 3 - 17.

Ooi , K., Abdul Rahman, T., Lin, B. T. B.-I. \& Yee-Loong, C. A., (2011). Are TQM practices supporting customer satisfaction and service quality?. Journal of Services Marketing, pp. 410-419. 